\title{
Hormone-mediated Down-Regulation of Hepatic Glutathione Synthesis in the Rat
}

Shelly C. Lu, John Kuhlenkamp, Carmen Garcia-Ruiz, and Neil Kaplowitz

Division of Gastrointestinal and Liver Diseases, Department of Medicine, University of Southern California

School of Medicine, Los Angeles, California 90033

\section{Abstract}

Our present work characterized the role of hormone-mediated signal transduction pathways in regulating hepatic reduced glutathione (GSH) synthesis. Cholera toxin, dibutyryl cAMP (DBcAMP), and glucagon inhibited GSH synthesis in cultured hepatocytes by $25-43 \%$. Cellular cAMP levels exhibited a lower threshold for stimulation of the GSH efflux than inhibition of its synthesis. The effect of DBcAMP was independent of the type of sulfur amino acid precursor and cellular ATP levels and unassociated with increased GSH mixed disulfide formation or altered GSH/oxidized glutathione ratio. In liver cytosols, addition of DBCAMP and cAMP-dependent protein kinase (A-kinase) inhibited GSH synthesis from substrates (cysteine, ATP, glutamate, and glycine) by $\sim 20 \%$ which was prevented by the A-kinase inhibitor. However, if only substrates of the second step in GSH synthesis were used ( $\gamma$-glutamylcysteine, glycine, and ATP), DBcAMP and A-kinase exerted no inhibitory effect. Phenylephrine, vasopressin, and phorbol ester also inhibited GSH synthesis in cultured cells by $\sim 20 \%$, and depleted cell GSH independent of the type of sulfur amino acid precursor. Cellular cysteine level was unchanged despite the significant fall in GSH after glucagon or phenylephrine treatment. Pretreatment with either staurosporine, $\mathbf{C}$-kinase inhibitor, or calmidazolium, a calmodulin inhibitor, partially prevented but, together, completely prevented the inhibitory effect of phenylephrine. The same combination had no effect on the inhibitory effect of glucagon. The effects of hormones were confirmed in both the intact perfused liver and after in vivo administration. Thus, two classes of hormones acting through distinct signal transduction pathways may down-regulate hepatic GSH synthesis by phosphorylation of $\boldsymbol{\gamma}$-glutamylcysteine synthetase. (J. Clin. Invest. 1991. 88:260-269.) Key words: $\mathrm{Ca}^{2+}$-calmodulin $\bullet$ cyclic adenosine monophosphate $\bullet \gamma$ glutamylcysteine synthetase $\bullet$ protein kinase $\mathrm{C} \cdot$ signal transduction

\section{Introduction}

Reduced glutathione (GSH) is a tripeptide, $\gamma$-glutamylcysteinylglycine, found in all mammalian tissues but with especially high hepatic levels. GSH defends against many toxins and free

Address reprint requests to Dr. Lu, Division of Gastrointestinal and Liver Diseases, LAC 11-221, Department of Medicine, University of Southern California School of Medicine, 2025 Zonal Avenue, Los Angeles, CA 90033.

Received for publication 30 August 1990 and in revised form 4 March 1991.

J. Clin. Invest

(c) The American Society for Clinical Investigation, Inc.

0021-9738/91/07/0260/10 \$2.00

Volume 88, July 1991, 260-269 radicals. It is also a storage form of cysteine $(1,2)$. Hepatic GSH levels fall after experimental stressful conditions such as shock, fasting, inflammation, and exhaustive exercise (3-9). Increased hepatic GSH efflux is at least partly responsible for the fall in liver GSH content during fasting and exhaustive exercise $(6,7)$. We recently reported that hormones whose effects are mediated via cyclic adenosine monophosphate (cAMP) stimulated sinusoidal GSH efflux and raised plasma GSH levels (10). These hormonal effects may have important physiological implications, and may underlie the hepatic GSH "stress response." Very little is known about the hormonal regulation of GSH synthesis. We therefore studied the regulation of hepatic GSH synthesis by different hormone-mediated signal transduction pathways.

\section{Methods}

\section{Materials}

GSH, collagenase (type IV), bovine serum albumin, L-methionine, Lcysteine, L-cystine, dithiothreitol (DTT), diethyl maleate (DEM), NADPH, 5,5'-dithiobis (2-nitrobenzoic acid), sodium EDTA, GSH reductase, cholera toxin, glucagon, dibutyryladenosine $3^{\prime}, 5^{\prime}$-cyclic monophosphate (DBcAMP), hydrocortisone, insulin, phenylephrine, [arginine]vasopressin, phorbol 12-myristate 13-acetate (PMA), phorbol 13-monoacetate (inactive phorbol), calmidazolium, porcine heart cAMP-dependent protein kinase, porcine heart cAMP-dependent protein kinase inhibitor, glutathione-S-transferases, and Hepes were purchased from Sigma Chemical Co., St. Louis, MO. Staurosporine was purchased from Kamiya Biomedical Co., Thousand Oaks, CA. DLButhionine-S-R-sulfoximine was obtained from Chemical Dynamics Corp., South Plainfield, NJ. DME/F12 medium was purchased from Gibco Laboratories, Grand Island, NY. Sulfur amino acid-free DME/ F12 medium (SAF) was custom made by Irvine Scientific, Irvine, CA. Fetal bovine serum was purchased from Gemini Bio-Products, Inc., Calabasas, CA. HPLC-grade methanol was purchased from Fisher Scientific Co., Springfield, NJ. The cAMP radioimmunoassay (RIA) kit was purchased from Biomedical Technologies, Inc., Stoughton, MA. Monochlorobimane was purchased from Molecular Probes, Inc., Eugene, OR. $\gamma$-Glutamylcysteine was prepared by enzymatic hydrolysis of oxidized GSH (11). All other reagents were of analytical grade and were obtained from commercial sources.

\section{Animals}

Male Sprague-Dawley rats (Hilltop Laboratory Animals, Inc., Scottsdale, PA), weighing 260-340 g for preparation of cell cultures and 260$320 \mathrm{~g}$ for liver cytosol experiments and in vivo experiments, were maintained on Purina Rodent Chow (Ralston Purina Co., St. Louis, MO) and water ad libitum.

1. Abbreviations used in this paper: A-kinase, cAMP-dependent protein kinase; ALT, alanine aminotransferase; $C$-kinase, protein kinase C; CT, cholera toxin; DBcAMP, dibutyryladenosine $3^{\prime}, 5^{\prime}$-cyclic monophosphate; DEM, diethyl maleate; $\mathrm{mBCl}$, monochlorobimane; SAF, sulfur amino acid-free. 


\section{Cell culture preparation}

Hepatocytes were isolated aseptically according to the method of Moldeus et al. (12). Initial cell viability was $\geq 90 \%$ as determined by $0.2 \%$ trypan blue exclusion. The basic medium was DME/F12, high glucose, containing $10 \%$ fetal bovine serum, insulin $(1 \mu \mathrm{g} / \mathrm{ml})$ and hydrocortisone $(50 \mathrm{nM}) .1 .5-2 \times 10^{6}$ cells in $5 \mathrm{ml}$ of basic medium were plated on $60 \times 15-\mathrm{mm}$ dishes precoated with rat tail collagen, incubated at $37^{\circ} \mathrm{C}$ in $5 \% \mathrm{CO}_{2}, 95 \%$ air. $2-3 \mathrm{~h}$ after plating medium was changed to basic medium omitting serum and to remove dead, unattached cells. Cell attachment averaged $\sim 50 \%$.

\section{GSH synthesis experiments in cultured hepatocytes}

$24 \mathrm{~h}$ after plating, cells were treated with the agent of interest (or vehicle) for variable periods of time. In addition, cellular GSH was acutely depleted by diethyl maleate (DEM, $0.2 \mathrm{mM}$ ) which forms a thioether conjugate with GSH. 30 min after DEM treatment, cells were washed free of DEM and replenished with fresh SAF medium supplemented with excess GSH precursor, methionine ( $1 \mathrm{mM})$, and the agent of interest. Total GSH (cell + medium) was measured by the GSH recycling assay of Tietze (13) at time $0,30,60$, and 120 min after this change in medium. At the end of the incubation period, medium was saved and cells were washed twice with Krebs buffer, pH $7.4(5 \mathrm{ml})$, detached by trypsin-EDTA $(0.05 \%, 0.02 \%$, respectively) for cell counting by both cell counter (Coulter Corp., Hialeah, FL) and hemocytometer and viability determination which was $\geq 90 \%$ by trypan blue exclusion. Cellular GSH was extracted with $10 \%$ trichloroacetic acid and measured in the supernatant samples after centrifugation at $13,000 \mathrm{~g}$ in a microfuge (Beckman Instruments, Inc., Fullerton, CA) for $1 \mathrm{~min}$ to remove the denatured proteins. For each condition and time point, mean values from triplicate plates were used. The rate of accumulation of total GSH after acute depletion with DEM was the GSH synthesis rate.

\section{GSH synthesis using in situ liver perfusion model}

The design, method, and apparatus for in situ liver perfusions were previously described (14). To measure GSH synthesis, rats were treated with DEM $(0.4 \mathrm{ml} / \mathrm{kg}$ i.p.) to deplete GSH $1 \mathrm{~h}$ before in situ liver perfusion. During liver perfusion, excess amounts of precursors for GSH synthesis (methionine $1 \mathrm{mM}$, serine $1 \mathrm{mM}$, glycine $10 \mathrm{mM}$, and glutamate $5 \mathrm{mM}$ ) were added to Krebs-Ringer buffer. The effects of glucagon $(50 \mathrm{nM})$ or phenylephrine $(10 \mu \mathrm{M})$ were studied by adding them to the buffer. Serial liver biopsies $(0.1-0.2 \mathrm{~g})$ were taken at times 0 (just before start of perfusion with precursor-rich buffer), 15, 30, and 45 min for GSH assay. For each in situ liver perfusion, the bile duct was cannulated with PE-10 tubing (Clay Adams, Parsippany, NJ) and bile was collected after a retrograde biliary infusion of $20 \mu \mathrm{mol} / \mathrm{kg}$ acivicin, an irreversible inhibitor of $\gamma$-glutamyl transpeptidase. During perfusions (45 min), adding taurocholate $(15 \mu \mathrm{M})$ to the buffer maintained bile flow. The perfusion rates were $4.56 \pm 0.15 \mathrm{ml} / \mathrm{min} \cdot \mathrm{g}$ liver, and the $\mathrm{O}_{2}$ uptakes were $2.23 \pm 0.12 \mu \mathrm{mol} / \mathrm{min} \cdot \mathrm{g}$ liver (mean $\pm \mathrm{SEM}, n=15$ ). These values agree with previous reports (14), and they were similar in the two treatment groups compared to controls. Perfusate samples were taken at the end of 5-min intervals. Bile samples were collected continuously every $15 \mathrm{~min}$. Liver, perfusate, and bile GSH were measured by the method of Tietze (13). The rate of accumulation of total GSH (liver, bile, and perfusate) was the GSH synthesis rate. Cell lysis was monitored by measuring glutathione S-transferase in the perfusates (15); no lysis was detected up to $45 \mathrm{~min}$.

\section{GSH synthesis experiments using monochlorobimane}

Monochlorobimane (mBCl) forms a fluorescent adduct with GSH. The reaction, catalyzed by GSH S-transferase, is very sensitive and specific for GSH. Measuring the adduct by fluorimeter in intact hepatocytes or cell free conditions with liver cytosol agrees with synthesis rates determined by the method of Tietze (16).

Preparing liver cytosol and using $\mathrm{mBCl}$ to determine GSH synthesis rates in liver cytosols were previously described (16). Briefly, liver cytosols were prepared from rats $1 \mathrm{~h}$ after intraperitoneal injection of DEM $(0.4 \mathrm{ml} / \mathrm{kg})$ to deplete liver GSH. The GSH synthesis rate was measured in cell-free conditions by adding cytosol $(0.125 \mathrm{ml} ; 4-7.5 \mathrm{mg}$ protein as measured by assay, Bio-Rad Laboratories, Richmond, CA) to the cuvette containing: $100 \mathrm{mM}$ Tris- $\mathrm{HCl}, 150 \mathrm{mM} \mathrm{KCl}, 20 \mathrm{mM}$ $\mathrm{MgCl}_{2}, 2 \mathrm{mM}$ EDTA, $\mathrm{pH} 7.3$, glutamate $(10 \mathrm{mM})$, glycine (10 mM), ATP (3 mM), cysteine + DTT (0.1-1.0 mM) plus $100 \mu \mathrm{M} \mathrm{mBCl}$ in a final volume of $2.5 \mathrm{ml}$ at $37^{\circ} \mathrm{C}$. The difference in initial rate of linear increase in fluorescence over 6-8 $\mathrm{min}$ with or without pretreatment of cytosol with buthionine sulfoximine $\left(5 \mathrm{mM}\right.$ for $5 \mathrm{~min}$ at $\left.37^{\circ} \mathrm{C}\right)$ is equivalent to the rate of GSH synthesis. This method assesses the formation of GSH as an end product from two steps: the formation of $\gamma$-glutamylcysteine from cysteine and glutamate (catalyzed by $\gamma$-glutamylcysteine synthetase) and the formation of GSH from $\gamma$-glutamylcysteine and glycine (catalyzed by GSH synthetase). To assess the second step in GSH synthesis, cytosol was added to the cuvette containing $100 \mathrm{mM}$ Tris- $\mathrm{HCl}, 150 \mathrm{mM} \mathrm{KCl,} 2$ mM EDTA, pH 7.3, substrates $\gamma$-glutamylcysteine + DTT $(0.2 \mathrm{mM})$, glycine $(10 \mathrm{mM})$, cofactors ATP $(3 \mathrm{mM})$ and $\mathrm{Mg}^{2+}(20 \mathrm{mM})$, plus $100 \mu \mathrm{M} \mathrm{mBCl}$ in a final volume of $2.5 \mathrm{ml}$ at $37^{\circ} \mathrm{C}$. The difference in rate of increase in fluorescence in the presence of all precursors and cofactors versus only $\gamma$-glutamylcysteine is equivalent to the rate of GSH synthesis catalyzed by GSH synthetase.

The effects of DBcAMP, and cAMP-dependent protein kinase (Akinase) on GSH synthesis rate were studied by adding them directly to the cytosol. The effects of cAMP-dependent protein kinase inhibitor (A-kinase inhibitor) on GSH synthesis rate were studied by preincubating it with the cytosol for $5 \mathrm{~min}$ at $37^{\circ} \mathrm{C}$.

\section{In vivo GSH synthesis experiments}

All in vivo experiments were carried out from 9:00 to 11:30 a.m. on fed rats.

Effects of DBCAMP. All rats were treated first with DEM $(0.4 \mathrm{ml} / \mathrm{kg}$ i.p.). $15 \mathrm{~min}$ later either DBcAMP ( $25 \mathrm{mg} / \mathrm{ml}$ saline) plus theophylline $(10 \mathrm{mg} / \mathrm{ml}$ saline) mixture or saline was given intraperitoneally $(0.2$ $\mathrm{ml} / 100 \mathrm{~g}$ ); $1 \mathrm{~h}$ later the rats were killed and GSH synthesis rates in liver cytosol in the presence of precursors cysteine, glutamate, and glycine were measured using $\mathrm{mBCl}$.

Effects of phenylephrine and glucagon. Under pentobarbital anesthesia $(50 \mathrm{mg} / \mathrm{kg}$ i.p. $)$, a carotid artery and a jugular vein were cannulated with PE-50 polyethylene tubing. Starting at time zero, blood samples $(0.25-0.4 \mathrm{ml})$ were obtained at 5-10-min intervals from the carotid artery for measurement of plasma GSH and glucose levels. Treatment groups received either phenylephrine $(50 \mathrm{nmol} / \mathrm{min})$ or glucagon $(52$ $\mathrm{pmol} / \mathrm{min}$, the dose that was previously established (10) to raise plasma glucose by $64 \%$ over baseline after $15 \mathrm{~min}$ of infusion). The paired control group received $0.9 \% \mathrm{NaCl}$ throughout. Infusions were $52 \mu \mathrm{l} /$ min by infusion pumps (Harvard Apparatus, S. Natick, MA) in all groups and total infusion times were $15 \mathrm{~min}$ (phenylephrine) and 30 min (glucagon). The blood taken was replaced by $\mathrm{NaCl}$ or phenylephrine/glucagon solutions. The animals' temperatures stayed between 37 and $38^{\circ} \mathrm{C}$ using a heating lamp. The animals were then exsanguinated and the livers homogenized for determination of GSH by the method of Tietze (13) and processed to prepare liver cytosol (16). GSH synthesis rates in liver cytosol were measured using $\mathrm{mBCl}$.

Plasma GSH level was measured by the method of Adams et al. (17). Briefly, $0.2 \mathrm{ml}$ of each blood sample was added immediately to 0.2 $\mathrm{ml}$ of $10 \mathrm{mM}$ DTNB in phosphate-buffered saline (pH 7.5) containing $12.5 \mathrm{mM} \mathrm{Na}_{4}$ EDTA. After gentle mixing, the samples were centrifuged for $1 \mathrm{~min}$ at $15,850 \mathrm{~g}$ in a Beckman Instruments, Inc. Microfuge $\mathrm{E}$ to remove blood cells. This did not cause detectable hemolysis. Total GSH concentration in the supernatant was measured by the method of Tietze (13). Plasma GSH concentration was calculated from the measured concentration and the hematocrit determined in heparinized capillary tubes.

Glucose level was measured from the same supernatant samples by the Sigma Diagnostic Glucose (Trinder) reagent. Plasma glucose level was calculated from the measured glucose level and the hematocrit. Alanine aminotransferase (ALT) level was measured from the terminal plasma samples of the phenylephrine-treated group and the controls by the Sigma Diagnostic ALT 50 kit. 
Measurement of efflux in cultured cells

All experiments were carried out $20-24 \mathrm{~h}$ after plating. The medium was aspirated, and cells were washed twice with Krebs-Henseleit buffer, supplemented with $12.5 \mathrm{mM}$ Hepes (pH 7.4), then incubated with $5 \mathrm{ml}$ of Krebs buffer at $37^{\circ} \mathrm{C}$ in $5 \% \mathrm{CO}_{2}$ for $90 \mathrm{~min}$. GSH was assayed on $500-\mu l$ aliquots of supernatant at $5,30,60$, and $90 \mathrm{~min}$ by the method of Tietze (13). The accumulation of GSH in the supernatant was linear over $90 \mathrm{~min}$; thus efflux rates were calculated by linear regression. In parallel experiments, cell lysis during the course of incubation was estimated by measuring the release of glutathione S-transferase from the cytosol into the supernatant as a fraction of total cellular enzyme activity (15). Cell lysis was $<5 \%$ and did not increase during 90 -min incubation. Cells were then processed as described in the synthesis experiments for cell count and GSH measurements. To measure cellular glutathione S-transferase content, cells were scraped off the plates with a rubber policeman and treated with $10 \%$ Triton X-100 in phosphate buffer saline $(1: 1, \mathrm{vol} / \mathrm{vol})$. After centrifugation in a microfuge, enzyme activity was measured as previously described (15).

In addition to measuring GSH efflux in Krebs buffer, estimates of GSH efflux were obtained using the percentage of total GSH accumulated in the medium after 2-h incubation during the synthesis experiment in the presence of culture medium (see above).

\section{Molecular forms of GSH}

Cultured hepatocytes were incubated with DBcAMP $(0.1 \mathrm{mM})$ for $4 \mathrm{~h}$ and cells were treated as described under the synthesis experiments. Cell-free extract after treatment with $10 \%$ trichloroacetic acid was derivatized and analyzed by high-performance liquid chromatography (HPLC) according to the method of Reed et al. (18) to determine the molecular forms of glutathione.

\section{Cellular ATP content}

Cultured hepatocytes were incubated with DBcAMP $(0.1 \mathrm{mM})$ or vehicle overnight and cellular ATP levels were determined by HPLC according to the method of Jones (19).

\section{Cyclic AMP assay}

Cellular cyclic AMP was measured by RIA according to the methods in the Biomedical Technologies, Inc. cAMP RIA kit (see Materials).

\section{Cysteine concentration}

Hepatocytes were plated in SAF medium supplemented with methionine $(1 \mathrm{mM})$ and incubated with glucagon $(300 \mathrm{nM})$, phenylephrine $(0.1 \mathrm{mM})$ or vehicle overnight. Cells $\left(\sim 10^{6}\right.$ per plate) were collected by detaching with trypsin-EDTA $(0.05 \%, 0.02 \%$, respectively), then centrifuged in a microfuge for $30 \mathrm{~s}$ to remove the trypsin-EDTA solution. Cells were then treated with $5 \%$ perchloric acid to precipitate the proteins and centrifuged for $1 \mathrm{~min}$ in a microfuge, and supernatant cysteine levels were determined according to the method of Gaitonde (20).

Cysteine levels were measured in liver homogenates at the end of in situ liver perfusion according to the method of Gaitonde (20).

\section{Statistical analysis}

For cultured cells, each cell prep was derived from one animal and triplicate plates were used for each condition as well as time points (control vs. treatment). The mean of each triplicate from one experiment was considered $n=1$ and the means of multiple experiments were compared by paired Student's $t$ test. For perfused liver and in vivo cytosol experiments, unpaired Student's $t$ test was used.

\section{Results}

\section{Effects of hormones on GSH synthesis and efflux in cultured hepatocytes}

Cyclic AMP-dependent factors. Cultured hepatocytes were incubated with DBcAMP $(0.1 \mathrm{mM})$ or cholera toxin (CT, $2 \mathrm{ng} /$ $\mathrm{ml}$ ) and cell GSH levels and GSH efflux were measured after
A

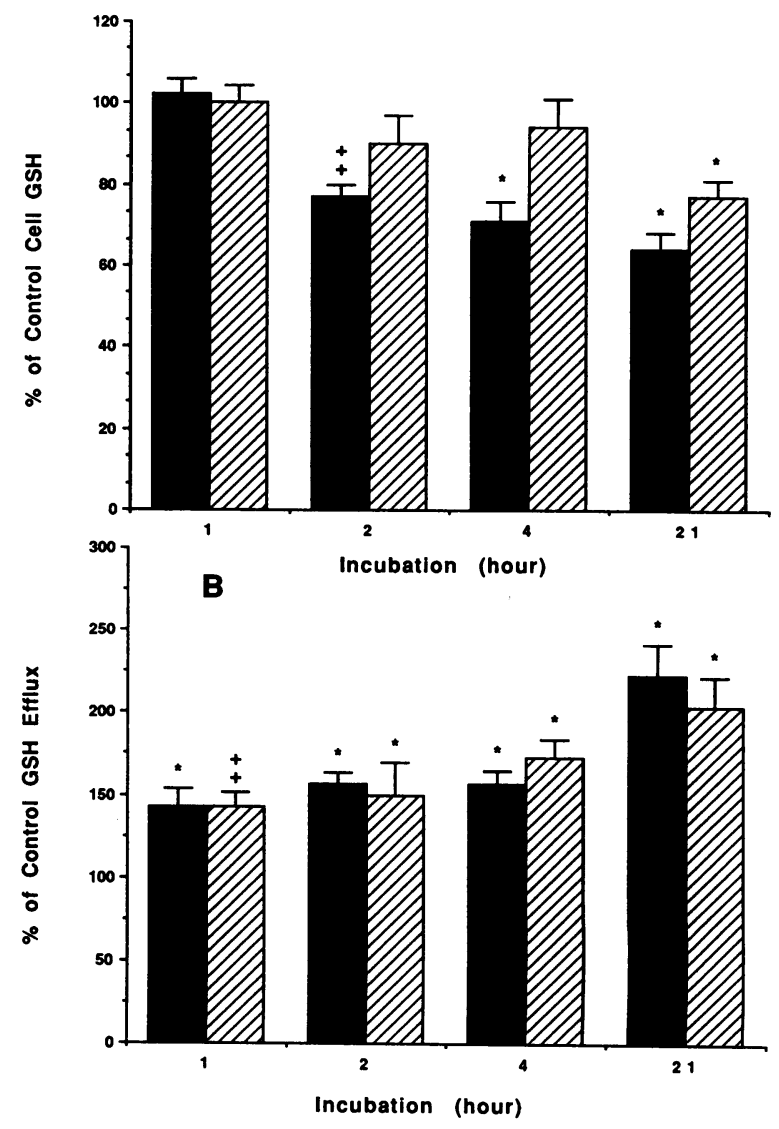

Figure 1. Effects of DBcAMP and CT on cell GSH $(A)$ levels and $(B)$ efflux. Cultured hepatocytes were incubated with DBcAMP $(a, 0.1$ $\mathrm{mM})$ or CT $(\square, 2 \mathrm{ng} / \mathrm{ml})$ for variable length of time. $(A)$ Cell GSH level fell significantly after $2 \mathrm{~h}$ of incubation with DBcAMP whereas it remained unchanged up to $4 \mathrm{~h}$ of incubation with CT. After $21 \mathrm{~h}$ of incubation with DBcAMP or CT, cell GSH levels were $64 \%$ and $77 \%$ of control values, respectively. (B) GSH efflux was stimulated to similar extents after $1 \mathrm{~h}$ of incubation with either DBcAMP or CT. Results from five to nine cell preps are expressed as the percentage of control values \pm SEM. Control values are as follows: Cell GSH ( $\mathrm{nmol} / 10^{6}$ cells): $127 \pm 29(1 \mathrm{~h}), 178 \pm 44(2 \mathrm{~h}), 113 \pm 24(4 \mathrm{~h})$, and $120 \pm 19(21 \mathrm{~h})$. GSH efflux (percentage of total GSH effluxed/h): $2.7 \pm 0.3(1 \mathrm{~h}), 3.2 \pm 0.5(2 \mathrm{~h}), 2.9 \pm 0.6(4 \mathrm{~h})$, and $2.6 \pm 0.3(21 \mathrm{~h}) .{ }^{*} P$ $<0.01,+P<0.05$ vs. control by paired Student's $t$ test.

variable periods of time. Cell GSH level fell significantly (77\% of control) after $2 \mathrm{~h}$ of incubation with DBcAMP, and fell further to $64 \%$ of control after $21 \mathrm{~h}$ of incubation (Fig. $1 \mathrm{~A}$ ). However, cell GSH level was maintained up to $4 \mathrm{~h}$ of incubation with CT but fell after overnight incubation. The fall in cell GSH after 2-4 h of incubation with DBcAMP cannot be explained by increased GSH efflux alone since both DBcAMP and CT stimulated GSH efflux to similar extents (Fig. $1 B$ ). This suggested GSH synthesis may be impaired in the presence of DBcAMP.

Fig. 2 illustrates results from one typical experiment comparing GSH synthesis in control and DBcAMP (0.1 mM)-pretreated cells. The rate of accumulation of total GSH was linear over $2 \mathrm{~h}$ and represents the GSH synthesis rate. Pretreatment with DBcAMP inhibited GSH synthesis.

The time course of the DBcAMP effect was studied by preincubating cells with $\mathrm{DBcAMP}(0.1 \mathrm{mM})$ for $30 \mathrm{~min}, 4$, or 


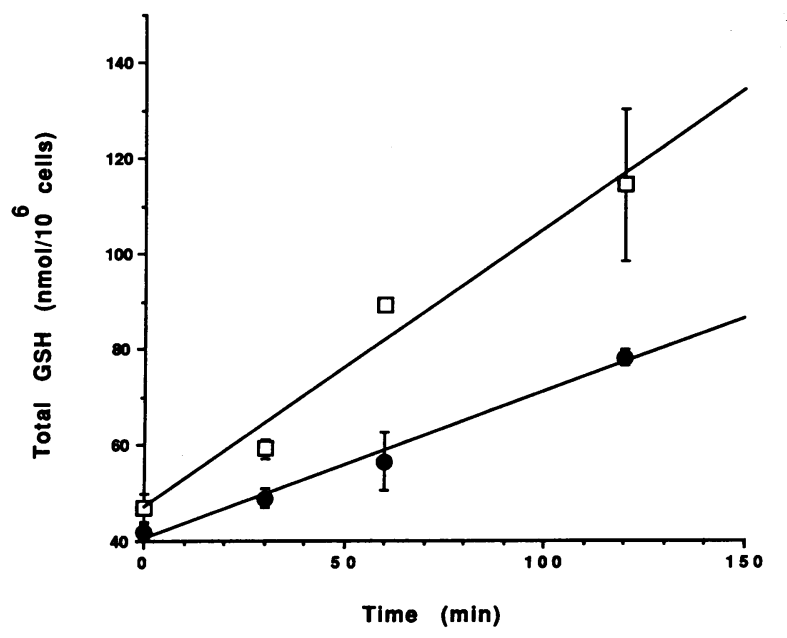

Figure 2. GSH synthesis after acute GSH depletion with DEM: one typical experiment. Total GSH (cell + medium) was measured at time $0,30,60$, and $120 \mathrm{~min}$ in culture medium containing excess methionine after acute GSH depletion with DEM $(0.2 \mathrm{mM})$ (see Methods). Control (ㅁ), DBcAMP (0.1 mM pretreated for $30 \mathrm{~min}$ ) (๑). Each data point represents the mean $\pm S E$ of triplicate determinations. The linear rate of accumulation of total GSH is the GSH synthesis rate. (See Methods for experimental details.)

$21 \mathrm{~h}$. The maximal inhibitory effect of DBcAMP on GSH synthesis was observed after $30 \mathrm{~min}$ of preincubation (Fig. 3). All subsequent studies with hormones and factors were done after $30 \mathrm{~min}$ of preincubation.

The dose response of DBcAMP inhibition of GSH synthesis was examined by preincubating cultured hepatocytes with varying doses of DBcAMP for 30 min. Table I shows maximum inhibition occurred with $100 \mu \mathrm{M} \mathrm{DBcAMP}$ and no effect occurred with $10 \mu \mathrm{M}$. On the other hand, the dose required to stimulate GSH efflux was $1 \mu \mathrm{M}$, with maximum effect at 10 $\mu \mathrm{M}$. Therefore, the thresholds of these two responses differ: a lower threshold for stimulation of GSH efflux and a higher threshold for inhibition of GSH synthesis. This phenomenon was further demonstrated with two other cAMP-dependent agents, CT and glucagon (Table II). The doses that stimulated GSH efflux (CT, $0.2 \mathrm{ng} / \mathrm{ml}$; glucagon, $10 \mathrm{nM}$ ) were $1 / 10$ th the doses that inhibited GSH synthesis (CT, $2 \mathrm{ng} / \mathrm{ml}$; glucagon, $140 \mathrm{nM}$ ). The corresponding cellular cAMP levels after treatment with CT or glucagon were measured by RIA (see Methods) at the end of $2 \mathrm{~h}$ of incubation. Fig. 4 demonstrates the relationship between cAMP level and stimulation of GSH efflux or inhibition of GSH synthesis mediated by CT and glucagon. At least a 45\% increase in cAMP level was required to inhibit GSH synthesis, whereas a $25 \%$ increase in cAMP level led to near maximal stimulation of GSH efflux with no effect on synthesis.

$\mathrm{Ca}^{2+}$ and protein kinase $\mathrm{C}$-dependent factors. The effects of phenylephrine and vasopressin on GSH synthesis were assessed after $30 \mathrm{~min}$ of preincubation. Table III shows both agents inhibited GSH synthesis by 20\%. Unlike cAMP-dependent factors, they did not affect GSH efflux.

\section{Effects of glucagon and phenylephrine on GSH synthesis in} the perfused liver

To confirm that the inhibitory effects of these hormones on GSH synthesis occur in models other than cultured hepatocytes, we measured GSH synthesis with or without hormone
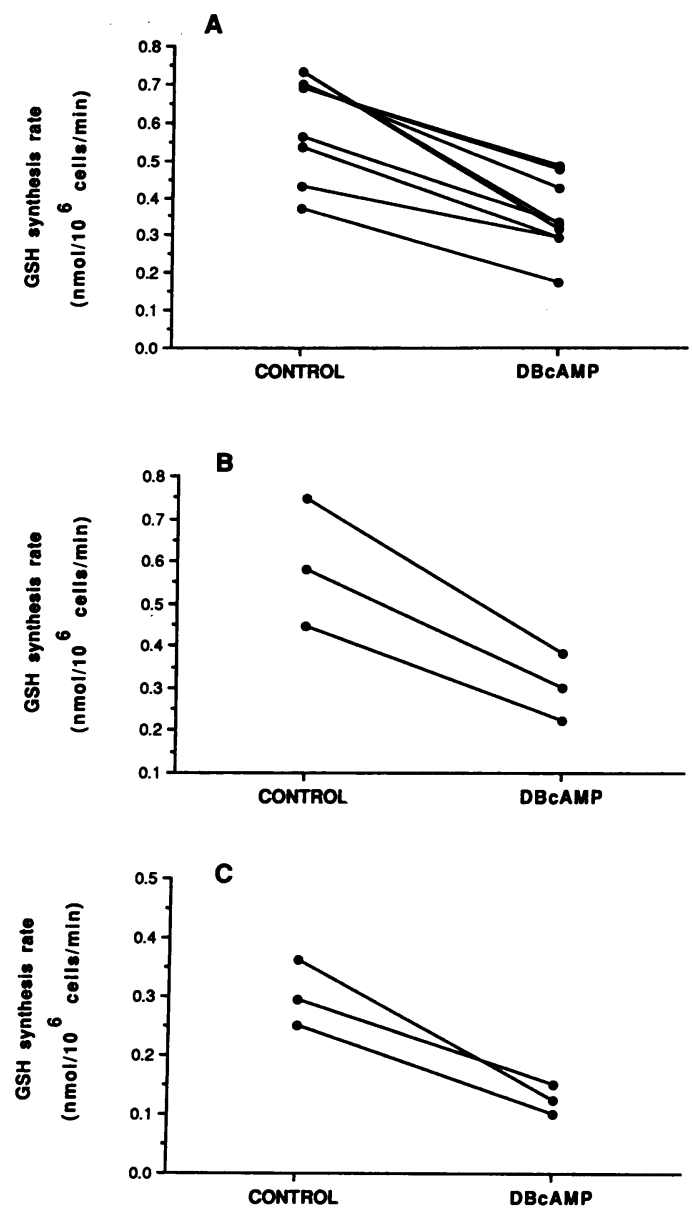

Figure 3. Time course of DBcAMP effect on GSH synthesis. Cultured hepatocytes were preincubated with $\operatorname{DBcAMP}(0.1 \mathrm{mM})$ for $30 \mathrm{~min}$ $(A), 4 \mathrm{~h}(B)$, or $21 \mathrm{~h}(C)$. Each data point represents the mean of triplicate determinations of the synthesis rate as illustrated in Fig. 2. Lines connect mean results from individual cell preps for paired control and treatment (DBcAMP). GSH synthesis rates were $57 \pm 3 \%(P<$ $0.0005), 51 \pm 1 \%(P<0.02)$, and $42 \pm 5 \%(P<0.05)$ of control after $30 \mathrm{~min}, 4$, and $21 \mathrm{~h}$ of preincubation with DBcAMP, respectively. The starting cell GSH levels were $80.8 \pm 14.9 \mathrm{nmol} / 10^{6}$ cells.

treatment in perfused liver (see Methods). Fig. 5 demonstrates significant inhibition $(\sim 50 \%)$ in GSH synthesis rates with either glucagon $(50 \mathrm{nM})$ or phenylephrine $(10 \mu \mathrm{M})$ treatment compared to controls ( $n=5$ for each group, $P<0.05$ by unpaired $t$ test).

\section{Role of different signal transduction pathways in the regulation of GSH synthesis in cultured hepatocytes}

Both phenylephrine and vasopressin activate $G_{p}$ protein which activates phospholipase $C$ and ultimately activates protein kinase $\mathrm{C}$ (C-kinase) and raises cytosolic $\mathrm{Ca}^{2+}$ level. One important consequence of raised cytosolic $\mathrm{Ca}^{2+}$ level is activation of a $\mathrm{Ca}^{2+}$ binding protein, calmodulin. Factors that raise intracellular cAMP levels not only activate A-kinase but also may increase intracellular $\mathrm{Ca}^{2+}$ level (21-23) and possibly activate $\mathrm{C}$ kinase. Therefore, any or all of these signal transduction pathways may be responsible for the effects of these hormones on GSH synthesis. The following series of experiments were designed to determine the role of each of these pathways and their interactions: 
Table I. Dose Response of DBcAMP on Inhibition of GSH Synthesis and Stimulation of GSH Efflux in Cultured Hepatocytes

\begin{tabular}{rccr}
\hline Dose & $\begin{array}{c}\text { Percentage of control } \\
\text { GSH synthesis }\end{array}$ & $\begin{array}{c}\text { Percentage of control } \\
\text { GSH efflux }\end{array}$ & $n$ \\
\hline$\mu M$ & & & \\
1 & $95 \pm 4$ & $125 \pm 2^{\ddagger}$ & 3 \\
10 & $102 \pm 3$ & $171 \pm 22^{\S}$ & 3 \\
100 & $57 \pm 3^{*}$ & $152 \pm 11^{*}$ & 9 \\
200 & $73 \pm 5^{\ddagger}$ & $194 \pm 12^{\S}$ & 4 \\
\hline
\end{tabular}

Values are percentage of control \pm SEM for the number of cell preps (n). Cells were preincubated with DBcAMP for $30 \mathrm{~min}$. The starting cell GSH levels after acute DEM depletion $\left(80.8 \pm 14.9 \mathrm{nmol} / 10^{6}\right.$ cells $)$ were similar in control and treated cells. Control values: GSH synthesis rate, $0.62 \pm 0.04 \mathrm{nmol} / 10^{6} \mathrm{per} \mathrm{min}$; GSH efflux, $6.2 \pm 0.45 \%$ of total GSH (cell + medium) at $2 \mathrm{~h}$

${ }^{*} P<0.0005 ;{ }^{\ddagger} P<0.005 ;{ }^{8} P<0.05$ vs. control by paired Student's $t$ test.

The C-kinase pathway was directly assessed by PMA (500 $\mathrm{nM}$ ), a C-kinase agonist which is also known to attenuate the glucagon-induced increase in cytoplasmic free $\mathrm{Ca}^{2+}$ concentration (24). Fig. 6 shows that treatment with PMA significantly inhibited GSH synthesis by $25 \%$, whereas treatment with inactive phorbol (500 $\mathrm{nM})$ was without effect. Staurosporine (10 nM), a C-kinase inhibitor (25) with $K_{\mathrm{i}}$ of $0.7 \mathrm{nM}$ for C-kinase (per Kamiya Biochem Co.) completely blocked the effect of PMA (500 nM). Calmidazolium, a calmodulin inhibitor with $\mathrm{IC}_{50}$ in the micromolar range (26), was used to examine the importance of the $\mathrm{Ca}^{2+}$-calmodulin pathway. Staurosporine $(10 \mathrm{nM})$ or calmidazolium $(1 \mu \mathrm{M})$ either alone or together had no effect on GSH synthesis but pretreatment with either agent partially blocked the effect of phenylephrine $(0.1 \mathrm{mM})$. Combining staurosporine and calmidazolium completely prevented the inhibitory effect of phenylephrine. On the other hand, the same combination had no effect on glucagon-mediated inhibi-

Table II. Effects of cAMP-dependent Factors on GSH Synthesis and Efflux in Cultured Hepatocytes

\begin{tabular}{cccr}
\hline Factor & $\begin{array}{c}\text { Percentage control } \\
\text { GSH synthesis }\end{array}$ & $\begin{array}{c}\text { Percentage of control } \\
\text { GSH efflux }\end{array}$ & $n$ \\
\hline CT $(n g / m l)$ & & & \\
0.2 & $98 \pm 4$ & $142 \pm 11^{\ddagger}$ & 3 \\
2 & $77 \pm 3^{*}$ & $138 \pm 9^{\ddagger}$ & 3 \\
20 & $70 \pm 6^{*}$ & $142 \pm 11^{*}$ & 3 \\
Glucagon (nM) & & & \\
1 & $95 \pm 4$ & $100 \pm 10$ & 3 \\
10 & $98 \pm 8$ & $132 \pm 6^{*}$ & 5 \\
140 & $70 \pm 6^{*}$ & $124 \pm 6^{*}$ & 4 \\
300 & $71 \pm 3^{5}$ & $143 \pm 9^{\ddagger}$ & 12 \\
& & &
\end{tabular}

Results are percentage of control \pm SEM for the number of cell preps (n). Cells were preincubated with varying doses of CT or glucagon for 30 min. Starting cell GSH levels after acute DEM depletion $\left(73.0 \pm 15.8 \mathrm{nmol} / 10^{6}\right.$ cells) were similar in the control and treatment groups. Control values: GSH synthesis rate, $0.60 \pm 0.05 \mathrm{nmol} / 10^{6}$ cells per min; GSH efflux, $7.20 \pm 0.63 \%$ of total GSH (cell + medium) at $2 \mathrm{~h}$.

${ }^{*} P<0.05 ;{ }^{\ddagger} P<0.01 ;{ }^{8} P<0.0002$ vs. control by paired Student's $t$ test.

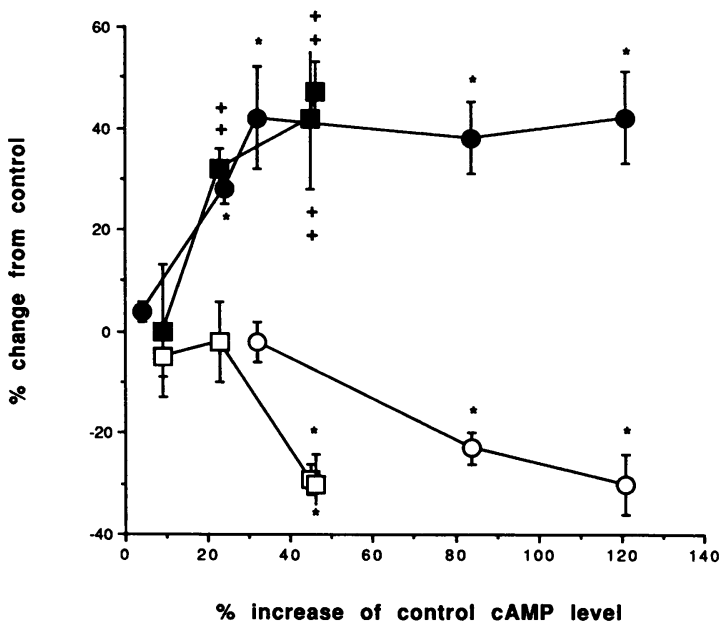

Figure 4. Relationship between cAMP levels and stimulation of GSH efflux or inhibition of GSH synthesis by CT and glucagon. Cells were incubated with varying doses of CT $(0.002,0.02,0.2,2$, and $20 \mathrm{ng} / \mathrm{ml})$ or glucagon $(1,10,140$, and $300 \mathrm{nM})$ for $30 \mathrm{~min}$ in culture medium and during the subsequent $90 \mathrm{~min}$ in Krebs buffer for determination of GSH efflux rates. GSH synthesis rates were measured over 120 min (as in Fig. 2) beginning after 30 min of preincubation with CT or glucagon and CAMP levels were measured by RIA at the end of the 2-h incubation in culture medium (see Methods). Results are expressed as percentage of change from control \pm SEM for three to nine cell preps. GSH efflux with CT treatment (๑), glucagon treatment (ם); GSH synthesis rates with CT treatment (o), glucagon treatment ( $(\mathrm{C})$. Note that a $25 \%$ increase in cAMP level led to stimulation in GSH efflux with both agents, whereas at least $45 \%$ increase in cAMP level was necessary to inhibit GSH synthesis. ${ }^{*} P<0.05,{ }_{+}^{+} P<0.01$ vs control by paired Student's $t$ test. Cell GSH was $120 \pm 19 \mathrm{nmol} / 10^{6}$ cells for the efflux experiments (without DEM pretreatment). Starting cell GSH was $73.0 \pm 15.84 \mathrm{nmol} / 10^{6}$ cells after DEM pretreatment, control synthesis rate was $0.597 \pm 0.05 \mathrm{nmol} / 10^{6}$ cells per min, GSH efflux was $3.27 \pm 0.37 \%$ of total GSH/h, and cAMP level was $14.4 \pm 2.1$ pmol $/ 10^{6}$ cells.

tion of hepatic GSH synthesis. Thus, both protein kinase $\mathrm{C}$ and $\mathrm{Ca}^{2+}$-calmodulin pathways mediate the inhibition of GSH synthesis by phenylephrine but do not mediate the effect of glucagon. This is further supported by the finding that combining

Table III. Effects of Phenylephrine and Vasopressin on GSH Synthesis and Efflux in Cultured Hepatocytes

\begin{tabular}{cccr}
\hline Factors & $\begin{array}{c}\text { Percentage of control } \\
\text { GSH synthesis }\end{array}$ & $\begin{array}{c}\text { Percentage of control } \\
\text { GSH efflux }\end{array}$ & $n$ \\
\hline$\mu M$ & & & \\
Phenylephrine & & & \\
1 & $104 \pm 6$ & $84 \pm 5$ & 3 \\
10 & $83 \pm 3^{*}$ & $88 \pm 9$ & 3 \\
100 & $76 \pm 2^{\ddagger}$ & $113 \pm 10$ & 10 \\
Vasopressin & & & \\
1 & $77 \pm 4^{*}$ & $104 \pm 10$ & 3 \\
\hline
\end{tabular}

Results are percentage of control \pm SEM for the number of cell preps (n). Starting cell GSH levels after acute depletion $\left(65.0 \pm 8.0 \mathrm{nmol} / 10^{6}\right.$ cells) with DEM were similar in the control and treatment groups. Control values: GSH synthesis rate, $0.58 \pm 0.05 \mathrm{nmol} / 10^{6}$ cells $/ \mathrm{min}$; GSH efflux, $6.23 \pm 0.56 \%$ of total GSH (cell + medium) at $2 \mathrm{~h}$.

${ }^{*} P<0.05 ;{ }^{\ddagger} P<0.0002$ vs. control by paired Student's $t$-test. 


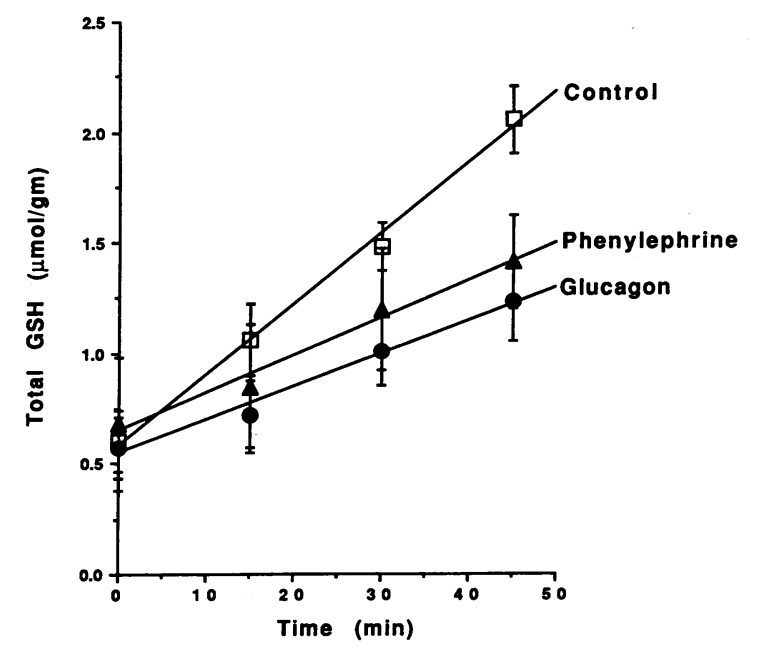

Figure 5. Effects of glucagon ( $50 \mathrm{nM})$ and phenylephrine $(10 \mu \mathrm{M})$ on GSH synthesis in the perfused liver. After acute GSH depletion with DEM $(0.4 \mathrm{ml} / \mathrm{kg}$ i.p.), hepatic GSH synthesis was estimated as the rate of accumulation of total GSH (liver, perfusate, and bile) during 45 min of perfusion with precursor-rich Krebs buffer (see Methods for details). Data points represent mean $\pm S E$ from five different animals. GSH synthesis rates (slope of linear regressions) were $15.05 \pm 3.37$ for glucagon ( $\bullet$ and $16.89 \pm 2.27 \mathrm{nmol} / \mathrm{g}$ per min for phenylephrine ( $\triangle$ )treated rats, both significantly different at $<0.05$ level from controls (ㅁ) $(31.79 \pm 4.70 \mathrm{nmol} / \mathrm{g}$ per min) by unpaired Student's $t$ test.

PMA (500 nM) and maximal dose of DBcAMP (0.1 mM) or glucagon $(300 \mathrm{nM})$ resulted in significantly greater inhibition than either agent alone (GSH synthesis rates: PMA, 0.46 \pm 0.04 ; glucagon, 0.40 \pm 0.06 ; DBcAMP, 0.39 \pm 0.06 ; PMA + glucagon,
$0.37 \pm 0.05 ; \mathrm{PMA}+\mathrm{DBcAMP}, 0.36 \pm 0.05 \mathrm{nmol} / 10^{6} \mathrm{cells} / \mathrm{min}$; five cell preps, $P<0.05$ by paired $t$ test).

GSH efflux was unaffected by treatments with PMA, staurosporine, and/or calmidazolium (data not shown).

\section{Mechanisms of inhibition of GSH synthesis}

Studies in cultured hepatocytes and in situ liver perfusions. Having established that both cAMP and $\mathrm{Ca}^{2+} / \mathrm{C}$-kinase signal transduction pathways independently lead to apparent inhibition of GSH synthesis, we considered the following possible mechanisms for inhibition of GSH synthesis in cultured cells: (a) decreased uptake of GSH precursors, methionine and cystine in cultured cells (cysteine in culture media is almost completely autoxidized to cystine) $(27,28) ;(b)$ decreased intracellular availability of L-cysteine, the rate-limiting factor in GSH synthesis; (c) decreased cofactor, ATP, needed for GSH synthesis; $(d)$ decreased enzyme activity in the transsulfuration pathway leading to diminished conversion of methionine to cysteine; $(e)$ increased hidden forms of GSH (those not measured by the recycling assay) such as GSH-cysteine mixed disulfides; and $(f)$ decreased enzyme activity in GSH synthesis pathway.

To search for a preferential defect in GSH precursor uptake and the role of the transsulfuration pathway, we measured cell GSH levels after overnight incubation with DBcAMP (0.1 mM), PMA (500 nM) or phenylephrine (0.1 mM) in SAF media supplemented with either methionine $(1 \mathrm{mM})$ or cystine $(0.5 \mathrm{mM})$. Table IV shows that regardless of the type of GSH precursor present, cell GSH level fell to a similar degree after overnight treatment with each of these agents. This argues against inhibition of membrane transport since two entirely different transport systems take up the amino acids. This also argues against inhibition of transsulfuration pathway causing decreased GSH synthesis since cystine bypasses this pathway.

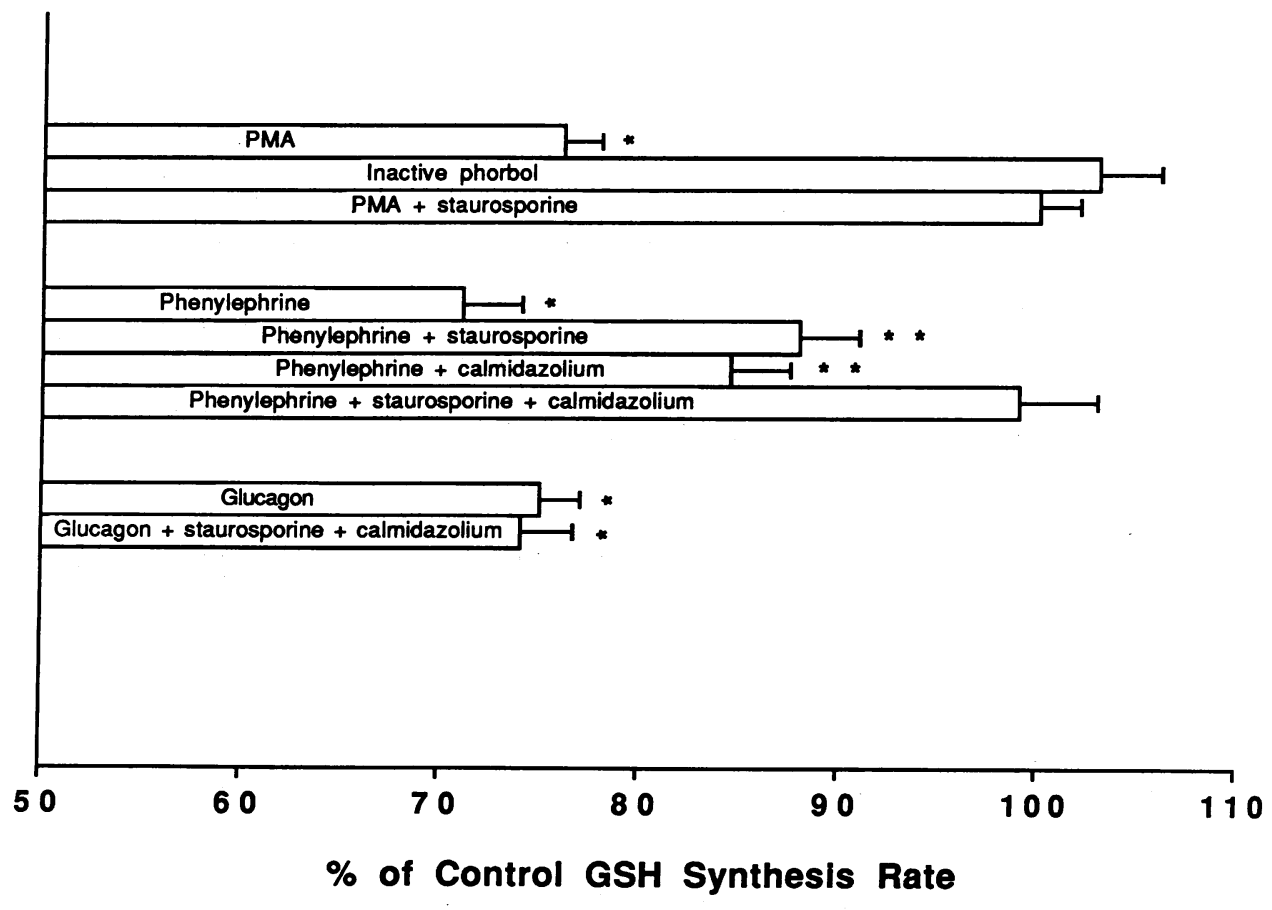

Figure 6. Roles of the protein kinase $\mathrm{C}$ and $\mathrm{Ca}^{2+}$-calmodulin pathways in mediating the effects of phenylephrine and glucagon on GSH synthesis in cultured hepatocytes. Cells were pretreated with staurosporine and/or calmidazolium for $5 \mathrm{~min}$ before PMA (500 nM), phenylephrine $(0.1 \mathrm{mM})$, or glucagon $(300 \mathrm{nM})$ was added. Staurosporine (10 $\mathrm{nM})$ or calmidazolium $(1 \mu \mathrm{M})$ either alone or together had no effect on GSH synthesis (not shown). Results are expressed as percentage of control \pm SEM for three to four cell preps. Treatment with PMA, phenylephrine, or glucagon resulted in $\sim 23-30 \%$ inhibition of GSH synthesis. Treatment with inactive phorbol $(500 \mathrm{nM})$ had no effect on GSH synthesis. The effect of PMA was blocked by pretreatment with staurosporine. Pretreatment with either staurosporine or calmidazolium attenuated the effect of phenylephrine, but combining staurosporine and calmidazolium completely

blocked the inhibitory effect of phenylephrine. The same combination had no effect on glucagon. Control GSH synthesis rates were $0.38 \pm 0.09$ $\mathrm{nmol} / 10^{6}$ cells per min. Starting cell GSH levels after acute depletion $\left(43.0 \pm 13.6 \mathrm{nmol} / 10^{6}\right.$ cells) with DEM were similar in the control and treatment groups. ${ }^{*} P<0.05$ vs. control; ${ }^{* *} P<0.05$ vs control and phenylephrine by paired Student's $t$ test. 
Table IV. Effects of Sulfur Amino Acid Precursor on the Inhibition of GSH Synthesis by DBCAMP, PMA and Phenylephrine in Cultured Hepatocytes

\begin{tabular}{cc}
\hline & Cell GSH \\
\hline & $n m o l / 10^{\circ}$ cells \\
SAF + methionine $(1 \mathrm{mM})$ & $205 \pm 29$ \\
+DBcAMP $(0.1 \mathrm{mM})$ & $136 \pm 17^{*}$ \\
SAF + cystine $(0.5 \mathrm{mM})$ & $154 \pm 23^{*}$ \\
+DBcAMP $(0.1 \mathrm{mM})$ & $89 \pm 18^{\ddagger}$ \\
SAF + methionine $(1 \mathrm{mM})$ & $181 \pm 37$ \\
+PMA $(500 \mathrm{nM})$ & $157 \pm 33^{*}$ \\
+ phenylephrine $(0.1 \mathrm{mM})$ & $153 \pm 31^{*}$ \\
SAF + cystine $(0.5 \mathrm{mM})$ & $124 \pm 38^{*}$ \\
+PMA $(500 \mathrm{nM})$ & $92 \pm 31^{\ddagger}$ \\
+phenylephrine $(0.1 \mathrm{mM})$ & $103 \pm 32^{\ddagger}$
\end{tabular}

Results are mean \pm SEM for four cell preps for both DBcAMP and $\mathrm{Ca}^{2+} / \mathrm{C}$-kinase-dependent factors. Cells were incubated with these agents overnight using SAF media supplemented with either methionine or cystine.

${ }^{*} P<0.05$ vs. SAF + methionine; ${ }^{\ddagger} P<0.05$ vs. SAF + cystine by paired Student's $t$ test.

To see if decreased intracellular availability of L-cysteine caused hormone-mediated inhibition, cultured hepatocytes were incubated overnight with glucagon $(300 \mathrm{nM})$, phenylephrine $(0.1 \mathrm{mM})$ or vehicle. Cellular cysteine level remained unchanged despite a significant fall in GSH compared to controls (Table V). Liver cysteine levels were also measured at the end of in situ liver perfusion experiments. There were no significant differences in liver cysteine levels after hormone treatments (control, 0.16 \pm 0.04 ; phenylephrine treated, $0.18 \pm 0.01$; glucagon treated, $0.19 \pm 0.07 \mathrm{mM}$ ). Therefore, the inhibition of GSH synthesis after hormone treatment was not due to limited availability of cysteine. This further excludes inhibitory effects on sulfur amino acid transport or transsulfuration as causing inhibition of cellular GSH synthesis.

To examine if depletion of cell ATP level caused decreased GSH synthesis, GSH synthesis rates and cell ATP levels were measured after overnight incubation with DBcAMP (0.1 mM). Results from three cell preps showed significant inhibition of GSH synthesis after overnight incubation with DBcAMP (control $0.30 \pm 0.03$ vs. DBcAMP $0.13 \pm 0.01 \mathrm{nmol} / 10^{6}$ cells $/ \mathrm{min}, P$

Table V. Effects of Overnight Glucagon (300 nM) and Phenylephrine (0.1 mM) Incubation on Cell GSH and Cysteine Levels

\begin{tabular}{lll}
\hline & Cell GSH & Cell cysteine \\
\hline & \multicolumn{3}{c}{ nmol/10 cells } \\
Control & $63.0 \pm 13.5$ & $4.2 \pm 0.4$ \\
Glucagon & $49.7 \pm 11.0^{*}$ & $4.4 \pm 0.6$ \\
Phenylephrine & $53.7 \pm 13.8^{\ddagger}$ & $4.0 \pm 0.7$
\end{tabular}

Results are in mean \pm SEM from three cell preps. Cells were plated in SAF medium supplemented with methionine $(1 \mathrm{mM})$ and incubated overnight with either glucagon $(300 \mathrm{nM})$ or phenylephrine $(0.1 \mathrm{mM})$. GSH and cysteine levels were measured $18 \mathrm{~h}$ later.

${ }^{*} P<0.05 ;{ }^{\ddagger} P<0.01$ vs. control by paired Student’s $t$ test.
$<0.05$ ) despite lower starting GSH levels exerting less feedback inhibition of GSH synthesis in the treatment group (control $40.7 \pm 10.9$ vs. DBcAMP $16.7 \pm 2.7 \mathrm{nmol} / 10^{6}$ cells, $P=0.1$ ). ATP level was not affected by treatment (control $23.5 \pm 2.94$ vs. DBcAMP $25.9 \pm 1.57 \mathrm{nmol} / 10^{6}$ cells).

To eliminate the possibility that DBcAMP treatment results in increased hidden forms of GSH, HPLC analysis on three cell extracts preps after treatment with DBcAMP $(0.1$ $\mathrm{mM}$ ) for $4 \mathrm{~h}$ demonstrated no increase in GSH-mixed disulfides nor any alteration in the GSH oxidized glutathione ratio in the DBcAMP-treated cells (not shown).

In the culture model, cell density can affect cell function $(29,30)$. The inhibitory effect on GSH synthesis of all of the agents examined was independent of cell density (data not shown).

Studies in cell-free conditions. To assess if the mechanisms involved in inhibiting GSH synthesis are directed within the cytosol, we measured GSH synthesis rates of liver cytosols by the $\mathrm{mBCl}$ technique (see Methods). We found a $24 \%$ inhibition in GSH synthesis from substrates (cysteine $0.1 \mathrm{mM}$, ATP 3 $\mathrm{mM}$, glutamate $10 \mathrm{mM}$, and glycine $10 \mathrm{mM}$ ) when DBcAMP (1 mM) was added directly to the cytosol (Table VI). In fresh cytosols (prepared the same day), addition of A-kinase (200 $\mu \mathrm{g} / \mathrm{ml}$ ) caused no further inhibition. However, if the cytosol was stored for $>5 \mathrm{~d}$ at $-80^{\circ} \mathrm{C}$, addition of DBcAMP alone was ineffective; both A-kinase and DBcAMP were necessary to inhibit GSH synthesis. Preincubation of liver cytosol with DBcAMP and A-kinase at $37^{\circ} \mathrm{C}$ for 5-7 min did not cause further inhibition. However, preincubation of liver cytosol with A-kinase inhibitor $(1 \mathrm{mg} / \mathrm{ml})$ for $5-7 \mathrm{~min}$ at $37^{\circ} \mathrm{C}$ was necessary in order to see its effect. Table VI shows that $\operatorname{DBcAMP}(\geq 10 \mu \mathrm{M})$ directly inhibited the rate of GSH synthesis by $20-25 \%$; A-kinase inhibitor prevented this. A-kinase or A-kinase inhibitor alone did not affect GSH synthesis.

To differentiate the effects of DBcAMP on the two steps in

Table VI. Effects of DBcAMP, A-kinase, and A-kinase inhibitor on GSH Synthesis in Cell-free Conditions

\begin{tabular}{lcr}
\hline & $\begin{array}{c}\text { Percentage of control } \\
\text { GSH synthesis rate }\end{array}$ & $n$ \\
\hline DBcAMP & & \\
$1 \mu \mathrm{M}$ & $96 \pm 2$ & 3 \\
$10 \mu \mathrm{M} \pm \mathrm{A}-$-kinase $(200 \mu \mathrm{g} / \mathrm{ml})^{*}$ & $80 \pm 2^{\ddagger}$ & 3 \\
$1 \mathrm{mM} \pm \mathrm{A}-\mathrm{kinase}(200 \mu \mathrm{g} / \mathrm{ml})$ & $76 \pm 6^{\ddagger}$ & 5 \\
A-kinase $(200 \mu \mathrm{g} / \mathrm{ml})$ & $99 \pm 3$ & 3 \\
A-kinase inhibitor $(1 \mathrm{mg} / \mathrm{ml})$ & $92 \pm 4$ & 4 \\
A-kinase inhibitor $(1 \mathrm{mg} / \mathrm{ml})+\mathrm{DBcAMP}$ & & \\
$\quad(1 \mathrm{mM})+$ A-kinase $(200 \mu \mathrm{g} / \mathrm{ml})$ & $92 \pm 3$ & 4 \\
& &
\end{tabular}

Results are in percentage of control \pm SEM of the number of cytosol $\operatorname{preps}(n)$. GSH synthesis rates were measured fluorometrically using $\mathrm{mBCl}$ by adding cytosol to the cuvette in the presence of the precursors for GSH: glutamate, glycine, and cysteine-DTT and cofactors, ATP, $\mathrm{Mg}^{2+}$ (see Methods).

* Addition of A-kinase was not necessary when fresh cytosol (prepared the same day) was used, but was necessary if the cytosol was stored $>5 \mathrm{~d}$ at $-80^{\circ} \mathrm{C}$. Pretreatment of cytosol with A-kinase inhibitor for $5-7 \mathrm{~min}$ at $37^{\circ} \mathrm{C}$ was necessary to see any effect. Pretreatment of cytosol with DBcAMP and A-kinase did not result in further inhibition. Control GSH synthesis rates were $2.62 \pm 0.09 \mathrm{nmol} / \mathrm{mg}$ protein per min.

${ }^{\ddagger} P<0.05$ vs control by paired Student’s $t$ test. 
GSH synthesis, liver cytosol was added to the cuvette with only substrates for the second step in GSH synthesis ( $\gamma$-glutamylcysteine, glycine, ATP, and $\mathrm{Mg}^{2+}$ ). Four cytosol preps showed addition of DBcAMP $(1 \mathrm{mM})$ and A-kinase $(200 \mu \mathrm{g} / \mathrm{ml})$ exerted no inhibitory effect under these conditions (GSH synthesis rates were $4.74 \pm 0.29$ in controls and $4.59 \pm 0.46 \mathrm{nmol} / \mathrm{mg}$ protein per min in treatment groups). Therefore, GSH synthetase activity is not affected by DBcAMP and A-kinase.

To ascertain whether DBcAMP treatment affects the $K_{\mathrm{m}}$ or $V_{\max }$ or both of $\gamma$-glutamylcysteine synthetase, GSH synthesis rates in liver cytosols were measured with or without DBcAMP $(1 \mathrm{mM})$ and A-kinase $(200 \mu \mathrm{g} / \mathrm{ml})$ while increasing the concentration of cysteine from 0.1 to 0.5 and $1.0 \mathrm{mM}$. Four cytosols preps showed that by increasing the concentration of cysteine from 0.1 to $0.5 \mathrm{mM}$, the rate of GSH synthesis increased by $40 \%(2.51 \pm 0.05$ vs. $3.48 \pm 0.06 \mathrm{nmol} / \mathrm{mg}$ per min, respectively); $1.0 \mathrm{mM}$ cysteine caused no further increase $(3.50 \pm 0.14 \mathrm{nmol} /$ $\mathrm{mg}$ per min). Addition of DBcAMP and A-kinase exerted a significant $(P<0.05)$ inhibitory effect on GSH synthesis rate as compared to controls at each cysteine concentration examined (84 $\pm 2 \%$ of control for $0.1 \mathrm{mM}$ cysteine, $74 \pm 8 \%$ of control for $0.5 \mathrm{mM}$ cysteine, and $84 \pm 1 \%$ of control for $1.0 \mathrm{mM}$ cysteine). This suggests DBcAMP treatment affects the $V_{\max }$.

In vivo experiments with $D B c A M P$, phenylephrine, and glucagon. To examine if the effects of DBcAMP on $\gamma$-glutamylcysteine synthetase could be reproduced in vivo, GSH synthesis rates of liver cytosols were measured fluorometrically using $\mathrm{mBCl}$ after rats were treated with DBcAMP and theophylline intraperitoneally (see Methods). Paired control liver cytosols ( $n$ $=4$ ) exhibited a GSH synthesis rate of $2.82 \pm 0.06 \mathrm{nmol} / \mathrm{mg}$ protein per min, whereas the treatment group $(n=4)$ showed a GSH synthesis rate of $2.21 \pm 0.15 \mathrm{nmol} / \mathrm{mg}$ protein per min (78\% of control, $P<0.02$ vs. control by unpaired $t$ test).

Similarly, GSH synthesis rates from precursors, cysteine $(0.1 \mathrm{mM})$, glutamate $(10 \mathrm{mM})$, and glycine $(10 \mathrm{mM})$, measured in liver cytosols of rats treated with intravenous phenylephrine $(50 \mathrm{nmol} / \mathrm{min})$ or glucagon $(52 \mathrm{pmol} / \mathrm{min})$ were significantly lower than paired controls. The phenylephrine group $(n=4)$ exhibited a GSH synthesis rate $(2.05 \pm 0.16 \mathrm{nmol} / \mathrm{mg}$ protein per min) $72 \%$ of its controls $(2.85 \pm 0.05 \mathrm{nmol} / \mathrm{mg}$ protein per min, $P<0.01$ by unpaired $t$ test) and the glucagon group ( $n$ $=4)$ exhibited a GSH synthesis rate $(2.35 \pm 0.06 \mathrm{nmol} / \mathrm{mg}$ protein per $\mathrm{min}) 83 \%$ of control $(2.83 \pm 0.16 \mathrm{nmol} / \mathrm{mg}$ protein per $\min , P<0.05$ by unpaired $t$ test). However, the GSH synthesis rate from precursors for the second step of GSH synthesis, $\gamma$ glutamylcysteine and glycine, were not significantly different in the phenylephrine $(4.16 \pm 0.67 \mathrm{nmol} / \mathrm{mg}$ protein per $\mathrm{min})$ or glucagon-treated $(3.36 \pm 0.39 \mathrm{nmol} / \mathrm{mg}$ protein per $\mathrm{min})$ groups and their respective controls $(5.06 \pm 0.36$ and $4.06 \pm 0.64 \mathrm{nmol} /$ mg protein per min, respectively). Interestingly, in contrast to our previous results with glucagon revealing elevated plasma GSH levels at the dose employed in the present studies (10), phenylephrine at the dose used $(50 \mathrm{nmol} / \mathrm{min})$ did not significantly change plasma GSH levels (not shown). However, before excluding an effect of phenylephrine in vivo on hepatic GSH efflux, turnover studies of plasma GSH will be required.

Plasma glucose level after $30 \mathrm{~min}$ of glucagon infusion was $222 \pm 31 \%$ of baseline values ( $n=4, P<0.02$ by paired $t$ test), whereas it remained unchanged after $30 \mathrm{~min}$ of infusion in the paired controls. Phenylephrine infusion produced no change in plasma glucose levels. Plasma ALT levels did not significantly differ in the phenylephrine-treated group compared to its controls.

\section{Discussion}

GSH is synthesized from precursor amino acids in virtually all cells (31). The liver plays a central role in the interorgan homeostasis of GSH and is unique in two aspects of GSH biosynthesis. First, it has the unique ability to convert methionine to cysteine through transsulfuration. Secondly, it is the major source of plasma GSH, exporting GSH into plasma and bile at a rate that matches nearly all of its biosynthesis. The synthesis of GSH from its constituent amino acids, glutamate, cysteine, and glycine, involves two ATP-requiring enzymatic steps: (1) $\gamma$-glutamyl-L-cysteine formation from L-glutamate and L-cysteine and (2) GSH formation from $\gamma$-glutamyl-L-cysteine and glycine. The first step is rate-limiting and catalyzed by $\gamma$-glutamylcysteine synthetase, regulated physiologically by $(a)$ feedback competitive inhibition by GSH and $(b)$ the availability of its precursor, L-cysteine $(1,31,32)$. Cysteine availability depends on transsulfuration of methionine as well as sulfur amino acid transport.

The distinct membrane transport of cysteine (ASC), cystine $\left(\mathrm{X}_{\mathrm{c}}^{-}\right)$, and methionine (L) have been well characterized in hepatocytes $(27,33)$. Normally, cystine uptake is insignificant. However, upon culturing rat hepatocytes, cystine uptake activity is induced after a 12-h lag. This increase in transport activity of cystine depends on de novo synthesis of both RNA and protein (34). This may be an adaptive response of cultured cells since no detectable cysteine is in the culture medium (almost completely autoxidized). Thus, for the cultured hepatocyte model, the factors determining the rate of GSH synthesis are methionine and cystine uptake, transsulfuration, activities of the GSH synthetic enzymes and cellular GSH level (feedback inhibition).

Hepatic GSH levels fall after stressful conditions such as shock, fasting, inflammation, and exhaustive exercise (3-9). Increased hepatic GSH efflux is at least partly responsible for the fall in liver GSH in fasting and exhaustive exercise $(6,7)$. Higashi and co-workers (35) demonstrated almost 15 years ago that administration of dibutyryl-3',5'-cyclic AMP (DBcAMP) to rats caused $\sim 50 \%$ decrease in liver GSH (35). Our own work (10) suggests cAMP stimulates sinusoidal GSH efflux while not affecting canalicular GSH efflux. Thus enhanced release of GSH may have caused part of the fall in liver GSH from DBcAMP. The only previous work to suggest hormonal regulation of GSH synthesis was that of Estrela and co-workers (36) who recently suggested that hormones which act through the $\mathrm{Ca}^{2+}$ and $\mathrm{C}$-kinase-dependent signal transduction mechanisms, such as phenylephrine, stimulated GSH efflux and inhibited GSH synthesis in hepatocytes isolated after a 48-h fast. They suggested the mechanism of phenylephrine-mediated inhibition of GSH synthesis was by limiting the availability of glutamate since they noted $50 \%$ decrease in intracellular glutamate level after $1 \mathrm{~h}$ of treatment with phenylephrine and the inhibition was overcome when glutamine level was increased to $10 \mathrm{mM}$. However, the $K_{\mathrm{m}}$ of $\gamma$-glutamylcysteine synthetase for glutamate is $\sim 2 \mathrm{mM}$ and ordinarily the intracellular glutamate level is almost 10 -fold higher and probably does not play a regulatory role in GSH synthesis $(27,37,38)$. Specifically, Thor and colleagues (38) showed that omission of glutamate from the medium had no effect on either glutamate pool size or the rate of GSH synthesis. Therefore, the significance of their findings (36) is unclear and may pertain only to the marked perturbation of a 48-h fast. Thus, although there have been suggestions that hormones modulate hepatic GSH turnover, 
comparison of several classes of hormones which act through different signal transduction mechanisms and the steps in GSH homeostasis affected have not been previously examined.

Two major classes of hormones which affect hepatocyte metabolism and transport are divided on the basis of their signal transduction mechanisms: cAMP (glucagon) and $\mathrm{Ca}^{2+} / \mathrm{di}-$ acylglycerol (vasopressin, phenylephrine). Increased cAMP activates A-kinase; increased cytosolic $\mathrm{Ca}^{2+}$ activates a number of $\mathrm{Ca}^{2+}$-binding proteins; one of the most important is calmodulin which in turn activates specific calmodulin-dependent kinases; and diacylglycerol, along with $\mathrm{Ca}^{2+}$, activates C-kinase. Factors that increase intracellular cAMP level have also been reported to increase intracellular $\mathrm{Ca}^{2+}$ and possibly activate C-kinase as well (21-23) so that it is important to ascertain if cellular effects of cAMP are via A-kinase or via the $\mathrm{Ca}^{2+} / \mathrm{C}$ kinase signaling pathways. These different signal transduction pathways modulate cell function through kinase-mediated phosphorylation of target proteins, sometimes in overlapping, redundant fashion.

In both cultured rat hepatocytes and perfused rat livers, cAMP, $\mathrm{Ca}^{2+}$, and protein kinase $\mathrm{C}$-dependent factors all inhibited GSH synthesis. In addition, cAMP, but not $\mathrm{Ca}^{2+}$ or protein kinase C-dependent factors also stimulated GSH efflux in cultured hepatocytes as we previously reported (10). Furthermore, we found that there is a difference in the threshold of the two cAMP-mediated effects, namely, stimulation of GSH efflux and inhibition of GSH synthesis. At a lower cAMP threshold ( $25 \%$ increase in cAMP level over control), GSH efflux is stimulated; whereas at least a $45 \%$ increase in cAMP level was necessary to inhibit GSH synthesis. Thus, the effect of cAMP on efflux and synthesis of GSH could be dissociated, proving that the two effects are not interdependent.

By using inhibitors of the different signal transduction pathways, we found that the effect of phenylephrine is mediated by both the $\mathrm{C}$-kinase and $\mathrm{Ca}^{2+}$-calmodulin pathways. Thus, either the C-kinase inhibitor, staurosporine, or the calmodulin inhibitor, calmidazolium, only partially reversed the effect of phenylephrine but together completely prevented phenylephrine-mediated inhibition of GSH synthesis. The inhibitory effect of glucagon, on the other hand, was not affected by pretreatment with both staurosporine and calmidazolium indicating that cAMP was not acting via $\mathrm{Ca}^{2+}$ or C-kinase to inhibit GSH synthesis indirectly. This suggests that A-kinase pathway mediates the inhibitory effect of glucagon on GSH synthesis.

As for the mechanism for inhibition of GSH synthesis in cultured cells, we considered limitation of sulfur amino acid precursors or cellular ATP which are necessary to support GSH synthesis versus direct inhibition of GSH synthetic enzymes. Our data excluded limitation of cellular ATP as the mechanism. The maintenance of cellular cysteine levels in the face of inhibition of GSH synthesis indicates that impaired sulfur amino acid transport or transsulfuration cannot explain the fall in GSH synthesis. Furthermore, we excluded oxidation or mixed disulfide formation of GSH leading to masking GSH levels. Finally, by using the $\mathrm{mBCl}$ technique to measure GSH synthesis rates in cell free conditions the inhibitory effect of cAMP via an A-kinase dependent mechanism was demonstrated directly under conditions of maximum precursor availability within the cytosol. The mechanism of cAMP and Akinase mediated inhibition is most likely phosphorylation of $\gamma$-glutamylcysteine synthetase which leads to alteration in the $V_{\max }$ of the enzyme.
Finally, the significance of our findings in the cultured cells and cell-free conditions were confirmed in in vivo models. Liver cytosol harvested from treated rats showed that both classes of hormones are capable of exerting an inhibitory effect on GSH synthesis in vivo. These in vivo experiments also confirmed the most likely target to be regulation of the activity of $\gamma$-glutamylcysteine synthetase since GSH synthesis rates were similar to controls in the presence of precursors for the second step of GSH synthesis. In the case of glucagon, the dose employed approximates physiologic in producing a less than maximum glucose response according to our previous data (10). With phenylephrine, however, more studies will be required to see if it exerts an effect on GSH synthesis in vivo at doses which exhibit a physiologic effect on the liver.

In summary, we found cAMP-dependent factors both stimulate GSH efflux and inhibit GSH synthesis, whereas $\mathrm{Ca}^{2+} / \mathrm{C}$ kinase-dependent factors inhibit GSH synthesis without affecting efflux. All three signal transduction pathways may lead to phosphorylation of GSH synthetic enzymes and account for the stress-induced fall in hepatic GSH. The physiological significance of hormonal regulation of hepatic GSH turnover, both increased GSH efflux and inhibition of GSH synthesis, remains a matter of speculation. Increased GSH export from the liver during stressful periods may be a mechanism for the liver to supply GSH to where it is needed. The hormonal dependence of GSH export may be part of a regulatory system to maintain the extracellular thiol redox balance in response to oxidant stress. GSH is also a source of cysteine. Therefore, increased export of GSH during starvation may be a means for the liver to supply cysteine to the rest of the body. More difficult to reconcile is what purpose would decreased hepatic GSH synthesis serve in response to stress. Normally, the cellular concentration of cysteine is very low since it is rapidly incorporated into GSH. Theoretically, this could be viewed as a buffering action to prevent accumulation of a potentially toxic amino acid since cysteine readily autoxidizes to cystine in the extracellular fluid, a process which generates toxic free radicals. A possible explanation is that normally the liver GSH level is high (5-10 $\mathrm{mM})$ and during stressful periods hepatic synthesis of "acute phase" proteins may be more important than synthesis of GSH. By down-regulating GSH synthesis, cysteine can be channeled into other synthetic pathways. Many of the acute phase proteins are rich in cysteine, and provide important contributions in neutralizing the harmful consequences of tissue injury. At the same time, the GSH reservoir in the liver is so large that inhibition of synthesis does not lead to a fall to critically low levels which threaten hepatocyte defense. Furthermore, although the levels fall, supply to other tissues is maintained by the stimulation of efflux. At present, this teleologic explanation for down-regulation of hepatic GSH synthesis represents but one plausible possibility and further work will be required to define the molecular mechanism of down-regulation of GSH synthesis and its physiologic significance.

\section{Acknowledgments}

This work was supported by National Institutes of Health grant DK30312, Veterans Administration Medical Research Funds, and the United Liver Association.

\section{References}

1. Kaplowitz, N., T. Y. Aw, and M. Ookhtens. 1985. The regulation of hepatic GSH. Annu. Rev. Pharmacol. Toxicol. 25:714-744. 
2. Tateishi, N., T. Higashi, A. Naruse, K. Nakashima, H. Shiozaki, and Y. Sakamoto. 1977. Rat liver glutathione: possible role as a reservoir of cysteine. $J$. Nutr. 107:51-60.

3. Beck, L. V., W. H. Linkenheimer, and A. Mariaccini A. 1954. Effects of tumbling trauma, scalding and hemorrhage on rat tissues nonprotein sulfhydryl Proc. Soc. Exp. Biol. Med. 86:823-827.

4. Reichard, S. M., N. M. Bailey, and M. J. Galvin. 1981. Alterations in tissue glutathione levels following traumatic shock. Adv. Shock. Res. 5:37-45.

5. Yamada, H. 1977. Anti-shock effect of reduced glutathione: effects of survival rate and metabolism in traumatic shock rats. Jpn. J. Anesthesiol. 26:640 645.

6. Lauterburg, B. H., J. D. Adams, and J. R. Mitchell. 1984. Hepatic glutathione homeostasis in the rat: efflux accounts for glutathione turnover. Hepatology. 4:586-590.

7. Lew, H., S. Pyke, and A. Quintanilha. 1985. Changes in the glutathione status of plasma, liver and muscle following exhaustive exercise in rats. Fed. Eur. Biochem. Soc. 185:262-266.

8. Hirota, M., M. Inoue, Y. Ando, K. Hirayama, Y. Morino, K. Sakamoto, K. Mori, and M. Akagi. 1989. Inhibition of stress-induced gastric injury in the rat by glutathione. Gastroenterology. 97:853-859.

9. Bragt, P. C., and I. L. Bonta. 1980. Oxidant stress during inflammation: Anti-inflammatory effects of antioxidants. Agents Actions. 10:536-539.

10. Lu, S., C. Garcia-Ruiz, J. Kuhlenkamp, M. Ookhtens, M. Salas-Prato, and N. Kaplowitz. 1990. Hormonal regulation of GSH efflux. J. Biol. Chem. 265:16088-16095.

11. Strumeyer, D., and K. Bloch. 1962. $\gamma$-L-Glutamyl-L-cysteine from glutathione. Biochem. Prep. 9:52-55.

12. Moldeus, P., J. Hogberg, and S. Orrenius. 1978. Isolation and use of liver cells. Methods Enzymol. 51:60-70.

13. Tietze, F. 1969. Enzymic method for quantitative determination of nanogram amounts of total and oxidized glutathione: applications to mammalian blood and other tissues. Anal. Biochem. 27:502-522.

14. Ookhtens, M., K. Hobdy, M. C. Corvasce, T. Y. Aw, and N. Kaplowitz. 1985. Sinusoidal efflux of glutathione in the perfused rat liver: evidence for a carrier-mediated process. J. Clin. Invest. 75:258-265.

15. Booth, J. B., E. Boyland, and P. Sims. 1961. An enzyme from rat liver catalyzing conjugations with glutathione. Biochem. J. 79:516-524.

16. Fernandez-checa, J. C., and N. Kaplowitz. 1990. The use of monochlorobimane to determine hepatic GSH levels and synthesis. Anal. Biochem. 190:212 219.

17. Adams, J. D., B. H. Lauterburg, and J. R. Mitchell. 1983. Plasma glutathione and glutathione disulfide in the rat: regulation and response to oxidative stress. J. Pharmacol. Exp. Ther. 227:749-754

18. Reed, D. J., J. R. Babson, P. W. Beatty, A. E. Brodie, W. W. Ellis, and D. W. Potter. 1980. High-performance liquid chromatography analysis of nanomole levels of gluathione, glutathione disulfide and related thiols and disulfides. Anal. Biochem. 106:55-62.

19. Jones, D. P. 1981. Determination of pyridine nucleotides in cell extracts by high-performance liquid chromatography. J. Chromatogr. 225:446-449.

20. Gaitonde, M. K. 1967. A spectrophotometric method for the direct determination of cysteine in the presence of other naturally occurring amino acids. Biochem. J. 104:627-633.

21. Mauger, J. P., and M. Claret. 1986. Mobilization of intracellular calcium by glucagon and cyclic AMP analogues in isolated rat hepatocytes. FEBS (Fed. Eur. Biochem. Soc.) Lett. 195:106-110.

22. Mine, T., I. Kojima, and E. Ogata. 1988. Evidence of cyclic AMP-independent action of glucagon on calcium mobilization in rat hepatocytes. Biochim. Biophys. Acta. 970:166-171.

23. Ruiz, M. B., B. Ochoa, and M. Lacort. 1990. Glucagon- and dibutyryl cyclic AMP produced inhibition of cholesterol ester hydrolase in isolated rat hepatocytes: role of calcium. J. Biochem. 107:476-479.

24. Staddon, J. M., and R. G. Hansford. 1986. 4-Phorbol 12-myristate 13-acetate attenuates the glucagon-induced increase in cytoplasmic free $\mathrm{Ca}^{2+}$ concentration in isolated rat hepatocytes. Biochem. J. 238:737-743.

25. Verme, T. B., R. T. Velarde, R. M. Cunningham, and S. R. Hootman 1989. Effects of staurosporine on protein kinase $C$ and amylase secretion from pancreatic acini. Am. J. Physiol. 257:G548-553.

26. Grasso, J. A., M. Bruno, A. A. Yates, L. Wei, and P. Epstein. 1990 Calmodulin dependence of transferrin receptor recycling in rat reticulocytes. Biochem. J. 266:261-272.

27. Bannai, S., and N. Tateishi. 1986. Role of membrane transport in metabolism and function of glutathione in mammals. J. Membr. Biol. 89:1-8.

28. Bannai, S., T. Ishii, A. Takada, and T. Noriko. 1989. Regulation of glutathione level by amino acid transport. In Glutathione Centennial. N. Taniguchi, T. Higashi, Y. Sakamoto, and A. Meister, editors. Academic Press, Inc., San Diego, CA. 407-421.

29. Ben-Ze'ev, A., G. S. Robinson, N. L. R. Bucher, and S. R. Farmer. 1988. Cell-cell and cell-matrix interactions differentially regulate the expression of hepatic and cytoskeletal genes in primary cultures of rat hepatocytes. Proc. Natl. Acad. Sci. USA 85:2161-2165.

30. Schleifer, L. S., I. B. Black, and L. M. Reid. 1989. Regulation of betaadrenergic receptor expression in rat liver. J. Cell. Physiol. 140:52-58.

31. Meister, A., and M. E. Anderson. 1983. Glutathione. Annu. Rev. Biochem. 52:711-760.

32. Richman, P. G., and A. Meister. 1975. Regulation of $\gamma$-glutamylcysteine synthetase by nonallosteric feedback inhibition by glutathione. J. Biol. Chem. 250:1422-1426.

33. Kilberg, M. S. 1982. Amino acid transport in isolated rat hepatocytes. $J$. Membr. Biol. 69:1-12.

34. Takada, A., and S. Bannai. 1984. Transport of cystine in isolated rat hepatocytes in primary culture. J. Biol. Chem. 259:2441-2445.

35. Higashi, T., N. Tateishi, A. Naruse, and Y. Sakamoto. 1976. Decrease of glutathione and induction of $\gamma$-glutamyltransferase by dibutyryl-3', $5^{\prime}$-cyclic AMP in rat liver. Biochem. Biophys. Res. Commun. 68:1280-1286.

36. Estrela, J. M., F. Gil, J. M. Vila, and J. Vina. 1988. $\alpha$-Adrenergic modulation of glutathione metabolism in isolated rat hepatocytes. Am. J. Physiol. 255:E801-805.

37. Tateishi, N., Y. Sakamoto, A. Takada and S. Bannai. 1989. Regulation of glutathione level in primary cultured hepatocytes. In Glutathione Centennial. N. Taniguchi, T. Higashi, Y. Sakamoto, and A. Meister, editors. Academic Press, Inc., San Diego, CA. 57-71.

38. Thor, H., P. Moldeus, and S. Orrenius. 1979. Metabolic activation and hepatotoxicity: effect of cysteine, $N$-acetylcysteine, and methionine on GSH biosynthesis and bromobenzene toxicity in isolated rat hepatocytes. Arch. Biochem. Biophys. 192:405-413. 